Satilmis Bilgin (1), Burcin Meryem Atak Tel (1), Tuba Taslamacioglu Duman (1), Ozge Kurtkulagi (D), Gizem Bakir Kahveci (D), Tugrul Sagdic (1), Gulali Aktas (1) Abant Izzet Baysal University Hospital, Department of Internal Medicine, Bolu, Turkey

\title{
Compliance to levothyroxine treatment of the patients with hypothyroidism during SARS-CoV-2 pandemic era
}

For citation: Mižnarodnij endokrinologičnij žurnal. 2021;17(2):103-107. doi: 10.22141/2224-0721.17.2.2021.230563

\begin{abstract}
Background. Hypothyroidism requires treatment with levothyroxine (L-T4) to keep patients euthyroid. The rate of hospital admissions for chronic conditions decreased during COVID-19 era. We aimed to observe whether hospital admissions of the patients with hypothyroidism decreased during COVID-19 compared to the same time period in 2019. We also aimed to find out the rate of treatment compliance in subjects with hypothyroidism during pandemic era. Materials and methods. This cross-sectional study was performed on patients who applied to Internal Medicine Department of Abant Izzet Baysal University Hospital, and who received L-T4 replacement therapy due to hypothyroidism. 108 hypothyroidism patients were included in the study with their consent forms. The patients were divided into 2 groups according to the treatment compliance; either as compliant or incompliant patients. Results. The last TSH level of compliant group was significantly lower than incompliant group $(p<0.001)$. The last fT4 level of the compliant group was significantly higher than that of the incompliant group $(p=0.04)$. The median of the LT-4 treatment used irregularly was $35(10-90)$ days in incompliant group and was $0(0-0)$ days in compliant group $(p<0.001)$. The number of irregularly L-T4 used days was significantly positively correlated with last TSH value $(r=0.564, p<0.001)$, and negatively correlated with last FT4 value $(r=-0.492$, $p<0.001)$. Mean corpuscular volume (MCV) of the compliant and incompliant groups were 85 (69.1-97.5) $f L$ and 89 (66-96.6) fL, respectively ( $p=0.03$ ). Retrospective nature and relatively small study population are two main limitations of our study. Conclusions. Compliance to treatment is very important to achieve euthyroid hormone levels in patients with hypothyroidism during COVID-19 pandemic. Elevated MCV levels could predict incompliance to treatment in hypothyroidism.
\end{abstract}

Keywords: hypothyroidism; levothyroxine; compliance; thyroid stimulation hormone

\section{Introduction}

Hypothyroidism is characterized with elevated thyroid stimulation hormone (TSH) and decreased free thyroxine (FT4) levels [1]. Subclinical and overt hypothyroidism is defined with a TSH level of 4.5-9.9 mU/L and higher than $10 \mathrm{mU} / \mathrm{L}$, respectively $[2,3]$. The incidence of the disease increases with age and is more common in women [4]. Causes of primary hypothyroidism include autoimmunity, drug use which impairs thyroid functions, radioiodine therapy, and elderly individuals who do not have a history of thyroid surgery $[5,6]$.

Thyroid stimulating hormone (TSH) is secreted from the pituitary gland and the TSH level and FT4 level are inversely proportional to the logarithm [7]. The slightest change in serum FT4 level can result in significant changes in the TSH level [8]. The laboratory reference range is generally defined as within the $95 \%$ confidence limits of a population with normal thyroid hormone tests. In some sources, the lower limit of TSH is stated as $0.2-0.4 \mathrm{mU} / \mathrm{L}$ and the upper limit as $2.4-4.2 \mathrm{mU} / \mathrm{L}[7,8]$.

When the diagnosis of hypothyroidism is confirmed, levothyroxine (L-T4) treatment is initiated and should be continued for lifelong $[9,10]$. Abnormal TSH levels are associated with an increased risk of cardiovascular disease [2, $3,11,12]$. L-T4 is one of the most used drugs in the world [13]. Treatment with L-T4 should be individualized to keep patients euthyroid. Reference ranges may differ in different societies [14]. After the patients became euthyroid with 
L-T4 replacement therapy, TSH and FT4 levels should be checked every 6-12 months and hormone levels should be kept in the reference range $[2,3]$. The treatment is individualized by dose adjustment with L-T4 replacement therapy. It is well tolerated by patients and compliance is generally very good $[2,3,15]$.

The rate of hospital admissions for chronic conditions decreased during COVID-19 era [16, 17]. Therefore, we aimed to observe whether hospital admissions of the patients with hypothyroidism decreased during COVID-19 compared to the same time period in 2019. We also aimed to find out the rate of treatment compliance in subjects with hypothyroidism during pandemic era. Finally, we studied possible laboratory indicators of treatment incompliance in this population.

\section{Methods}

\section{Study population}

This cross-sectional study was performed on patients who applied to Internal Medicine Department of Abant Izzet Baysal University Hospital, and who received L-T4 replacement therapy due to hypothyroidism. Ethics committee approval of the institution was obtained (Decision No: 2020/205). 108 hypothyroidism patients were included in the study with their consent forms. Patients who applied to internal medicine clinics with medication, hypothyroidism control and/or other complaints, who were known to have a diagnosis of hypothyroidism before and who received L-T4 replacement therapy for at least 1 year were included in the study. Patients using L-T4 for less than 1 year, patients with a diagnosis Hashimoto's thyroiditis but not using L-T4, patients using L-T4 incompliantly before pandemic period, patients with hyperthyroidism, acute thyroiditis, subacute thyroiditis, Riedel thyroiditis, patients with thyroid malignancy, pregnant women, who take L-T4 after a meal were excluded from the study (14 patients).

In our country, starting from March 2020 of SARS-CoV-2 to occur, due to the fear of being infected with the coronavirus patients in 2020 March, April and May were asked if they compliantly use the L-T4 replacement therapy. The patients were divided into 2 groups according to the treatment compliance; either as compliant or incompliant patients.

\section{Laboratory analyses}

General characteristics (age, sex, height, weight), chronic diseases and medications and laboratory data of the participants, including TSH, FT4, white blood cell count (WBC), neutrophil count (NEU), lymphocyte count (LYM), eosinophil count (EOS), hemoglobin ( $\mathrm{Hb})$, hematocrit (HTC), mean corpuscular volume (MCV), red cell distribution width (RDW), platelet count (PLT), mean platelet volume (MPV), platelet distribution width (PDW), blood urea, serum creatinine and glomerular filtration rate were recorded. Height and weight of the patients were measured, and BMI was calculated by weight $(\mathrm{kg}) /$ height $\left(\mathrm{m}^{2}\right)$ formula.

\section{Statistical analyses}

All data were analyzed by SPSS software (SPSS 16.0 for Windows, IBM Co., Chicago, IL, USA). KolmogorovSmirnov test was used to examine the distribution of study parameters between the groups. Comparison of homogeneous parameters was performed by independent samples $t$ test and expressed as Mean $\pm \mathrm{SD}$ while non-homogeneous parameters were compared by Mann-Whitney U test and expressed as Median (Min-max). The Chi-Square Test was used to compare categorical variables between the groups and these variables were expressed as percentage. The correlation between study variables were evaluated by Pearson's correlation analysis test. Statistical significance was set on a $p$ value lower than 0.05 .

\section{Results}

The number of admissions with a diagnosis of hypothyroidism between March to May in 2020 was 159 and was significantly reduced compared to the same time period in 2019, which was 504 means that nearly $69 \%$ reduced. After exclusion criteria applied, a total of 94 subjects; $65(69.14 \%)$ in compliant and $29(30.86 \%)$ in incompliant group were included to the study. 82 of subjects were women and 12 were men. $57(88 \%)$ of the compliant subjects were women and $8(12 \%)$ of them were men, while $25(86 \%)$ of the incompliant subjects were women and $4(14 \%)$ were men $(\mathrm{p}=0.84)$. The ages of compliant and incompliant groups were 54 (19-87) and 46.5 (19-68), respectively $(\mathrm{p}=0.049)$.

Daily L-T4 doses in compliant and incompliant groups were $100(25-300) \mathrm{mcg}$ and $100(25-150) \mathrm{mcg}(\mathrm{p}=0.52)$. The initial TSH level of the compliant group was 1.17 (0.01-100) $\mathrm{mIU} / \mathrm{L}$ and was significantly lower than that of the incompliant group $(3.9(0.05-40) \mathrm{mIU} / \mathrm{L})(\mathrm{p}<0.001)$. The initial fT4 level of the compliant group (1.03 $(0.7-$ $1.45) \mathrm{ng} / \mathrm{dl})$ was significantly higher than that of the incompliant group $(0.93(0.62-1.32) \mathrm{ng} / \mathrm{dl})(\mathrm{p}=0.024)$. The last TSH level of compliant group was 1.19 (0.0110.4) $\mathrm{mIU} / \mathrm{L}$ and significantly lower than incompliant group $(6.56(0.76-100) \mathrm{mIU} / \mathrm{L})(\mathrm{p}<0.001)$. The last fT4 level of the compliant group was $1.12(0.68-1.65) \mathrm{ng} / \mathrm{dl}$ and was significantly higher than that of the incompliant group $(0.89(0.55-1.27) \mathrm{ng} / \mathrm{dl})(\mathrm{p}=0.04)$. The median of the LT-4 treatment used irregularly was 35 (10-90) days in incompliant group and was $0(0-0)$ days in compliant group $(\mathrm{p}<0.001)$.

Neutrophil count of the compliant and incompliant groups was $4.07(1.76-9.73) \mathrm{k} / \mathrm{mm}^{3}$ and $4.17(2.82-$ $6.44) \mathrm{k} / \mathrm{mm}^{3}$, respectively $(\mathrm{p}=0.049)$. Lymphocyte count of the compliant and incompliant groups were $2(0.86-$ $4.08) \mathrm{k} / \mathrm{mm}^{3}$ and $2.36(0.9-3.29) \mathrm{k} / \mathrm{mm}^{3}$, respectively $(\mathrm{p}=0.02)$. Mean corpuscular volume $(\mathrm{MCV})$ of the compliant and incompliant groups were 85 (69.1-97.5) fL and 89 (66-96.6) fL, respectively $(\mathrm{p}=0.03)$. Hb, Hct, PLT, WBC, EOS, RDW, PDW, MPV, blood urea, creatinine and glomerular filtration rate of the compliant and incompliant groups were not statistically different $(\mathrm{p}>0.05$ for all). 
The number of irregularly L-T4 used days was significantly positively correlated with last TSH value $(r=0.564$, $\mathrm{p}<0.001)$, and negatively correlated with last FT4 value $(\mathrm{r}=-0.492, \mathrm{p}<0.001)$. The last TSH level higher than $1.84 \mathrm{mIU} / \mathrm{L}$ has $90 \%$ sensitivity and $71 \%$ specificity in detecting treatment incompliance (Fig. 1). Moreover, the last FT4 level higher than $0.96 \mathrm{ng} / \mathrm{dl}$ has $81 \%$ sensitivity and $69 \%$ specificity in detecting treatment compliance (Fig. 2).

Sixty of $65(92.3 \%)$ subjects in compliant group were reached euthyroid level and $5(7.7 \%)$ remained hypothyroid, while 9 of 29 (31\%) subjects in incompliant group reached euthyroid level and $20(69 \%)$ remained hypothyroid $(\mathrm{p}<0.001)$.

\section{Discussion}

Striking results of present study are: a) the number of the hospital admissions of the patients with hypothyroidism was significantly reduced in 2020 compared to the same time period in 2019; b) both the initial and the last TSH levels were lower in compliant group compared to the incompliant group; c) both the initial and the last FT4 levels were higher in compliant group compared to the incompliant group; d) $\mathrm{MCV}$, neutrophil and lymphocyte counts were significantly lower in compliant group compared to the incompliant group; e) significantly more subjects reached euthyroid hormone levels in compliant group compared to the incompliant group.

The fear of being infected with novel coronavirus, SARS-CoV-2, is the main obstacle for the mediocre admissions of the patients with chronic conditions. Authors observed the admissions to dermatology clinic during April and May in 2019 and compared to the admissions in the

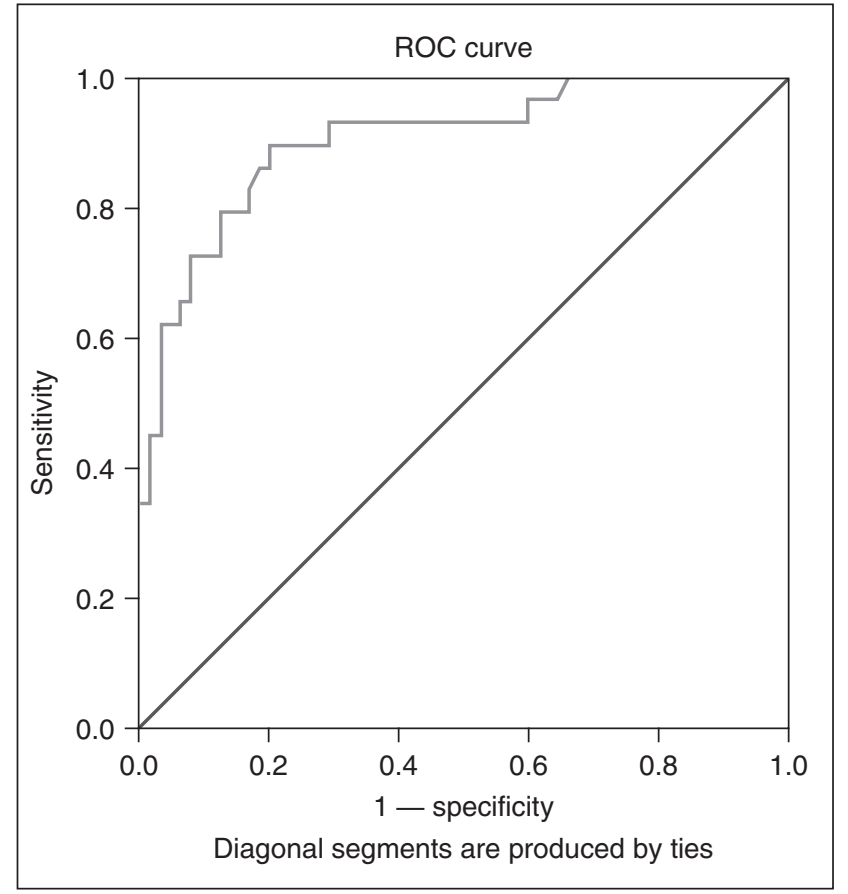

Figure 1. The ROC curve of last TSH value in predicting incompliant users same time period in 2020 in a novel study from China and reported that admissions in 2020 were nearly $61 \%$ reduced compared to the admissions in 2019 [18]. Moreover, A.B. Silva et al. studied the subjects with obstructive pyelonephritis before and during COVID-19 pandemic and reported that subjects during COVID-19 era presented to the healthcare facilities later, have higher rates of perirenal abscess and other complications and stayed in hospital longer than the subjects before pandemic [19]. Authors studied the effects of COVID-19 on cardiovascular mortality and cardiac catheterization activity in Germany and concluded that catheterization activities were decreased and cardiovascular mortality was incremented during lockdown of the country [20]. In another study, it has been reported that hospital admissions due to cardiovascular events were significantly reduced during COVID-19 outbreak [21]. Emergency admissions to the trauma services were also reduced by $26-37 \%$ as reported in a study from United Kingdom [22]. The rate of the admissions due to trauma during March-April 2019 and compared to the rates in same time period in 2020 in Ireland and a $40 \%$ reduction in 2020 has been found [23]. In 2020, hospital admissions in March and April were reduced down to the $23 \%$ of the admissions observed in January and February in Malta [24]. In present study, we found that hospital admissions due to hypothyroidism were $69 \%$ decreased in 2020 compared to the same time period in 2019.

Medicare seek is not negligible for all causes of hospital admissions. For instance, hospital admission is inevitable for patients with severe cardiovascular or neurovascular conditions. Hospital admissions due to myocardial infarction and stroke was remained unchanged while admissions due to unstable angina pectoris and heart failure were reduced

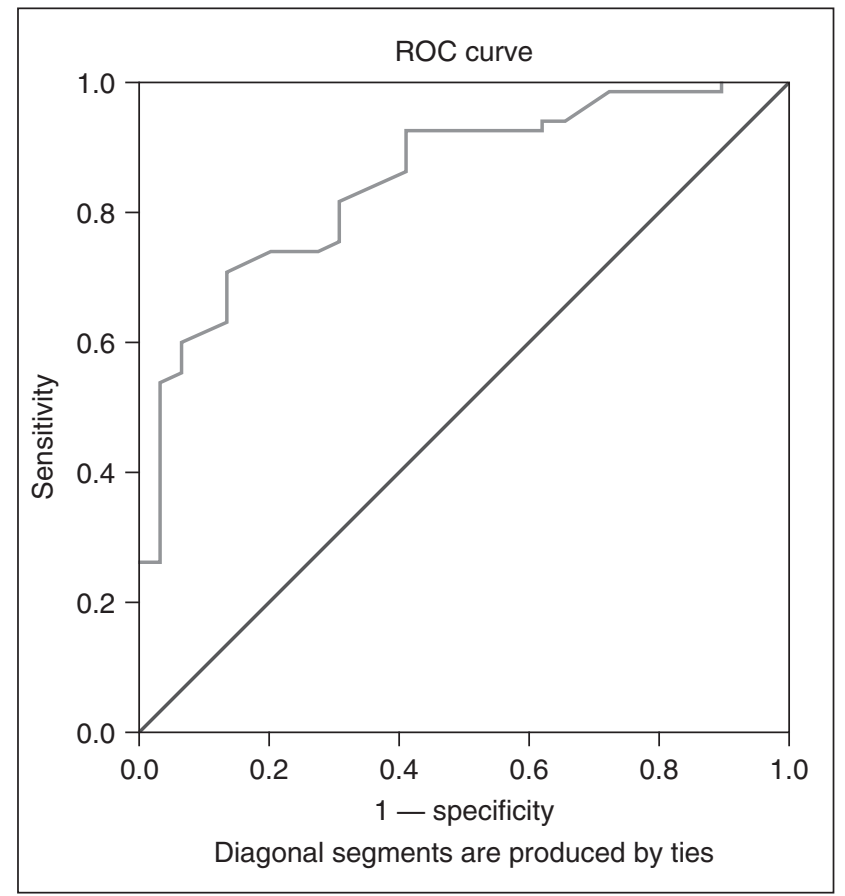

Figure 2. The ROC curve of last fT4 value in predicting compliant users 
during COVID-19 pandemic as reported in a recent study from Germany [21]. Since severe clinical picture related to the hypothyroidism is rare, admissions of the patients with hypothyroidism were reduced sharply in pandemic era in our study.

Adherence to the treatment has pivotal role in the success of the management of the chronic diseases. Therefore, these conditions are well controlled in patients with treatment compliance. More patients were compliant to the treatment in well controlled hypertension group compared to the poorly controlled hypertension group in a recent analysis [25]. Indeed, in present study, less subjects reached euthyroid hormone levels in incompliant group compared to the compliant group. Moreover, TSH levels were lower and FT4 levels were higher in compliant group compared to the incompliant subjects in present report. These laboratory results could be the reflection of inadequate adherence to the LT4 treatment.

The MCV levels were lower in compliant group than those in incompliant group. Hypothyroidism is associated with macrocytosis [26]. Incompliant group were tender to remain hypothyroid than compliant group in present study. Therefore, MVC levels could be detected higher in this group compared to compliant subjects. Neutrophil and lymphocyte counts were also lower in compliant group than incompliant patients. However, it is unclear whether these laboratory results were coincidental or caused by an underlying hematopoiesis mechanism, which should be elucidated.

Retrospective nature and relatively small study population are two main limitations of our study. However, to the best of our knowledge, this is the first study in literature analyzed admissions of the hypothyroid patients during COVID-19 pandemic and association between treatment compliance and reaching euthyroid hormone levels.

In conclusion, we think that compliance with treatment is very important to achieve euthyroid hormone levels in patients with hypothyroidism during COVID-19 pandemic. Moreover, elevated MCV levels could predict incompliance with treatment in hypothyroid subjects.

\section{References}

1. McDermott MT. Hypothyroidism. Ann Intern Med. $2020 \mathrm{Jul}$ 7;173(1):ITC1-ITC16. doi:10.7326/AITC202007070.

2. Garber JR, Cobin RH, Gharib H, et al; American Association of Clinical Endocrinologists and American Thyroid Association Taskforce on Hypothyroidism in Adults. Clinical practice guidelines for hypothyroidism in adults: cosponsored by the American Association of Clinical Endocrinologists and the American Thyroid Association. Endocr Pract. 2012 Nov-Dec;18(6):988-1028. doi:10.4158/ EP12280.GL.

3. Cooper DS, Biondi B. Subclinical thyroid disease. Lancet. 2012 Mar 24;379(9821):1142-54. doi:10.1016/S01406736(11)60276-6.

4. Leng $O$, Razvi S. Hypothyroidism in the older population. Thyroid Res. 2019 Feb 8;12:2. doi:10.1186/s13044-019-0063-3.

5. Ingoe L, Phipps N, Armstrong G, Rajagopal A, Kama- li F, Razvi S. Prevalence of treated hypothyroidism in the community: Analysis from general practices in North-East England with implications for the United Kingdom. Clin Endocrinol (Oxf). 2017 Dec;87(6):860-864. doi:10.1111/cen.13440.

6. Brown SJ, Bremner AP, Hadlow NC, et al. The log TSH-free T4 relationship in a community-based cohort is nonlinear and is influenced by age, smoking and thyroid peroxidase antibody status. Clin Endocrinol (Oxf). 2016 Nov;85(5):789-796. doi:10.1111/cen.13107.

7. Razvi S, Bhana S, Mrabeti S. Challenges in Interpreting Thyroid Stimulating Hormone Results in the Diagnosis of Thyroid Dysfunction. J Thyroid Res. 2019 Sep 22;2019:4106816. doi:10.1155/2019/4106816.

8. Fitzgerald SP, Bean NG. Thyroid stimulating hormone (TSH) autoregulation reduces variation in the TSH response to thyroid hormones. Temperature (Austin). 2018 Oct 8;5(4):380-389. doi:10.1080 /23328940.2018.1513110.

9. Hennessey JV, Espaillat R. Current evidence for the treatment of hypothyroidism with levothyroxine/levotriiodothyronine combination therapy versus levothyroxine monotherapy. Int J Clin Pract. 2018 Feb;72(2):e13062. doi:10.1111/ijcp.13062.

10. Jonklaas J, Bianco AC, Bauer AJ, et al; American Thyroid Association Task Force on Thyroid Hormone Replacement. Guidelines for the treatment of hypothyroidism: prepared by the american thyroid association task force on thyroid hormone replacement. Thyroid. 2014 Dec;24(12):1670-751. doi:10.1089/thy.2014.0028.

11. Taylor PN, Razvi S, Pearce SH, Dayan CM. Clinical review: A review of the clinical consequences of variation in thyroid function within the reference range. J Clin Endocrinol Metab. 2013 Sep;98(9):3562-71. doi:10.1210/jc.2013-1315.

12. Biondi B. The normal TSH reference range: what has changed in the last decade? J Clin Endocrinol Metab. 2013 Sep;98(9):3584-7. doi:10.1210/jc.2013-2760.

13. Cerqueira C, Knudsen N, Ovesen L, et al. Doubling in the use of thyroid hormone replacement therapy in Denmark: association to iodization of salt? Eur J Epidemiol. 2011 Aug;26(8):629-35. doi:10.1007/s10654-011-9590-5.

14. Hoermann R, Midgley JE. TSH Measurement and Its Implications for Personalised Clinical Decision-Making. J Thyroid Res. 2012;2012:438037. doi:10.1155/2012/438037.

15. Chen Y, Tai HY. Levothyroxine in the treatment of overt or subclinical hypothyroidism: a systematic review and meta-analysis. Endocr J. 2020 Jul 28;67(7):719-732. doi:10.1507/endocrj.EJ190583 .

16. De Filippo O, D'Ascenzo F, Angelini $F$, et al. Reduced Rate of Hospital Admissions for ACS during Covid-19 Outbreak in Northern Italy. N Engl J Med. 2020 Jul 2;383(1):88-89. doi:10.1056/NEJMc2009166.

17. Mafham MM, Spata E, Goldacre R, et al. COVID-19 pandemic and admission rates for and management of acute coronary syndromes in England. Lancet. 2020 Aug 8;396(10248):381-389. doi:10.1016/S0140-6736(20)31356-8.

18. Zhang Y, Wen J, Alamgir M, et al. Impact of the COVID-19 pandemic on inpatient dermatology: a multicentre study from Hubei, China. J Eur Acad Dermatol Venereol. 2021 Mar;35(3):e179-e181. doi:10.1111/jdv.17041.

19. Silva AB, Freschi G, Carrera RV, et al. COVID-19 pandemic impact on clinical outcomes of patients with obstructive pyelonephritis. Int Urol Nephrol. 2021 Apr;53(4):627-633. doi:10.1007/ 


\section{s11255-020-02708-3.}

20. Nef HM, Elsässer A, Möllmann H, et al; CoVCAD-Study Group. Impact of the COVID-19 pandemic on cardiovascular mortality and catherization activity during the lockdown in central Germany: an observational study. Clin Res Cardiol. 2021 Feb;110(2):292301. doi:10.1007/s00392-020-01780-0.

21. Stöhr E, Aksoy A, Campbell M, et al. Hospital admissions during Covid-19 lock-down in Germany: Differences in discretionary and unavoidable cardiovascular events. PLoS One. 2020 Nov 20;15(11):e0242653. doi:10.1371/journal.pone.0242653.

22. Karia M, Gupta V, Zahra W, Dixon J, Tayton E. The effect of COVID-19 on the trauma burden, theatre efficiency and training opportunities in a district general hospital: planning for a future outbreak. Bone Jt Open. 2020 Aug 18;1(8):494-499. doi:10.1302/26331462.18.BJO-2020-0074.R1.

23. Fahy S, Moore J, Kelly M, Flannery O, Kenny P. Analysing the variation in volume and nature of trauma presentations during COVID-19 lockdown in Ireland. Bone Jt Open. 2020 Nov 1;1(6):261266. doi:10.1302/2046-3758.16.BJO-2020-0040.R1.

24. Grech V, Borg D, Agius S, Scherb H. WITHDRAWN: Sharp decline in acute and elective hospital attendances and admissions due to COVID-19 in Malta (Q1 2020) - A population-based study. Early Hum Dev. 2020 Nov 12:105250. doi:10.1016/j.earlhumdev.2020.105250.

25. Atik F, Aktas G, Kocak MZ, Erkus E, Savli H. Analysis of the Factors Related to the Blood Pressure Control in Hypertension. J Coll Physicians Surg Pak. 2018 Jun;28(6):423-426. doi:10.29271/ jcpsp.2018.06.423.

26. Erdogan M, Kösenli A, Ganidagli S, Kulaksizoglu M. Characteristics of anemia in subclinical and overt hypothyroid patients. Endocr J. 2012;59(3):213-20. doi:10.1507/endocrj.ej11-0096.

Received 16.01.2021

Revised 25.02.2021

Accepted 02.03.2021

\section{Information about authors}

Satilmis Bilgin, MD, Assistant Professor, Abant Izzet Baysal University Hospital, Department of Internal Medicine, Bolu, Turkey; https://orcid.org/0000-0003-2811-0052 Burcin Meryem Atak Tel, MD, Assistant Professor, Abant Izzet Baysal University Hospital, Department of Internal Medicine, Bolu, Turkey; https://orcid.org/0000-0003-4201-9757 Tuba Taslamacioglu Duman, MD, Assistant Professor, Abant Izzet Baysal University Hospital, Department of Internal Medicine, Bolu, Turkey; https://orcid.org/0000-0002-3836-2125 Ozge Kurtkulagi, MD, Assistant Professor, Abant Izzet Baysal University Hospital, Department of Internal Medicine, Bolu, Turkey; https://orcid.org/0000-0002-4162-5563 Gizem Bakir Kahveci, MD, Assistant Professor, Abant Izzet Baysal University Hospital, Department of Internal Medicine, Bolu, Turkey; https://orcid.org/0000-0003-4520-4085 Tugrul Sagdic, MD, Abant Izzet Baysal University Hospital, Department of Internal Medicine, Bolu, Turkey; https://orcid.org/0000-0003-3174-3606 Gulali Aktas, MD, Professor, Abant Izzet Baysal University Hospital, Department of Internal Medicine, Bolu, Turkey; https://orcid.org/0000-0001-7306-5233

Conflicts of interests. Authors declare the absence of any conflicts of interests and their own financial interest that might be construed to influence the results or interpretation of their manuscript. Author contributions: Burcin Meryem Atak Tel, Satilmis Bilgin and Gulali Aktas — designed the study; Gizem Bakir Kahveci, Tugrul Sagdic and Ozge Kurtkulagi — performed obtaining literature knowledge; Tuba Taslamacioglu Duman, Burcin Meryem Atak Tel and Gulali Aktas — performed statistical analyses; Gulali Aktas, Tugrul Sagdic and Satilmis Bilgin — wrote the manuscript; Gizem Bakir Kahveci, Ozge Kurtkulagi and Tuba Taslamacioglu Duman — performed critical review of the first draft.

Funding: none received.

Satilmis Bilgin, Burcin Meryem Atak Tel, Tuba Taslamacioglu Duman,

Ozge Kurtkulagi, Gizem Bakir Kahveci, Tugrul Sagdic, Gulali Aktas

Abant Izzet Baysal University Hospital, Department of Internal Medicine, Bolu, Turkey

\section{Комп^аєнс АО Аікування левотироксином хворих на гіпотиреоз піА час панАемічної ери SARS-CoV-2}

Резюме. Актуальність. Гіпотиреоз потребує замісної терапії левотироксином (L-T4), щоб підтримувати в пацієнтів стан еутиреозу. Кількість госпіталізацій з приводу хронічних захворювань зменшилась протягом ери COVID-19. Mema дослідження - встановити частоту госпіталізацій пацієнтів з гіпотиреозом під час пандемії COVID-19 порівняно з аналогічним періодом часу в 2019 році. Матеріали та методи. Дослідження було проведене серед пацієнтів, які звернулись у відділення внутрішньої медицини університетської лікарні Abant Izzet Baysal та отримували замісну терапію L-T4 внаслідок гіпотиреозу. 108 пацієнтів з гіпотиреозом були включені в дослідження, підписавши інформаційну згоду. Пацієнти були розділені на дві групи відповідно до прихильності до лікування: хворі, які відповідали вимогам лікування, і хворі, які не дотримувались режиму лікування. Результати. Рівень тиреотропного гормона (ТТГ) перед включенням у дослідження у групі осіб, які відповідали вимогам лікування, був вірогідно нижчим, ніж у групі хворих, які не дотримувались режиму лікування ( $<<0,001)$. При цьому рівень вільного тироксину
(вТ4) серед пацієнтів першої групи був вірогідно вищим, ніж в осіб другої групи $(\mathrm{p}=0,04)$. Медіана нерегулярного прийому левотироксину становила 35 (10-90) днів у групі осіб, які не відповідали вимогам лікування, і 0 (0-0) днів у групі осіб, які відповідали вимогам лікування ( $<0,001)$. Кількість днів, коли левотироксин використовувався нерегулярно, вірогідно позитивно корелювала з останнім значенням ТТГ $(\mathrm{r}=0,564, \mathrm{p}<0,001)$ та негативно - - останнім значенням вT4 (r = -0,492, p < 0,001). Середній об'єм еритроцитів (MCV) у хворих першої та другої груп становив $85(69,1-97,5)$ та 89 (66-96,6) фл відповідно $(\mathrm{p}=0,03)$. Ретроспективний характер та порівняно невелика кількість досліджуваних були двома основними обмеженнями проведеного дослідження. Висновки. Дотримання режиму лікування є дуже важливим для досягнення стану еутиреозу в пацієнтів з гіпотиреозом під час пандемії COVID-19. Підвищений рівень MCV може передбачати невідповідність лікування у хворих на гіпотиреоз.

Ключові слова: гіпотиреоз; левотироксин; комплаєнс; тиреотропний гормон 